\title{
MANAJEMEN PENGEMBANGAN KEPROFESIAN BERKELANJUTAN (PKB) BAGI GURU DAN KEPALA SEKOLAH
}

\author{
Mulyono \\ Universitas Islam Negeri Maulana Malik Ibrahim Malang \\ e-mail: mulyonouin@gmail.com
}

\begin{abstract}
The purpose of this study is to examine the management of sustainable professional development (SPD) for teachers and principals. By using library research methods and content analysis techniques, the results of this study can be concluded as follows: First, sustainable professional development management is a competency development program for teachers and principals which is implemented according to the needs, gradually, continuously to improve teacher professionalism. Secondly, teachers and principals are obliged to carry out SPD activities in stages at each level of their ranks with the aim that every teacher and headmaster can maintain, improve, and expand their knowledge and skills to carry out the learning process professionally. The big goal of the SPD activity is the realization of quality learning to improve abilities in the fields of knowledge, skills and attitudes of students. Third, the implementation of sustainable professional development management includes planning, implementing, evaluating, and reflecting activities designed to improve characteristics, knowledge, understanding, and skills. Through an evaluation cycle, reflection on learning experiences, planning and implementation of teacher professional development activities on an ongoing basis, it is hoped that teachers and principals will be able to accelerate the development of pedagogical, professional, social, and personality competencies for career advancement. Fourth, teachers and principals can implement sustainable professional development management through several programs, namely: 1) Self-development, which includes: a) following functional training; and b) carrying out teacher collective activities. 2) Scientific publications, which include: a) making scientific publications on research results; and b) make book publications. 3) Innovative works, which include: a) discovering fixed technology; b) find / create art; c) create / modify learning tools; and d) follow the development of standards, guidelines, questions and the like. Fifth, with the realization of sustainable professional development management for teachers and principals that are programmed in stages and tiered it is expected to improve: 1) the professionalism of each teacher and school principal; 2) improve the quality of learning and competence of students in the mastery of knowledge, skills and attitudes; 3) improve the quality of education nationally in order to realize the nation's competitiveness Indonesia in the global era.
\end{abstract}

Keywords: Management; Development; Professionalism; Sustainability; Headmaster

Abstrak. Tujuan penelitian ini untuk mengkaji manajemen pengembangan keprofesian berkelanjutan bagi guru dan kepala sekolah. Dengan menggunakan metode penelitian kepustakaan (library research) dan teknik analisis isi (content analisys), maka hasil penelitian ini dapat disimpulkan berikut: Pertama, manajemen pengembanagan keprofesian berkelanjutan adalah program pengembangan kompetensi guru dan kepala sekolah yang dilaksanakan sesuai dengan kebutuhan, secara bertahap, berkelanjutan untuk meningkatkan profesionalitas guru. Kedua, guru dan kepala sekolah berkewajiban melaksanakan program PKB secara bertahap pada setiap jenjang kepangkatan mereka dengan tujuan agar setiap guru dan kepala sekolah dapat memelihara, meningkatkan, dan memperluas pengetahuan dan keterampilannya untuk melaksanakan proses pembelajaran secara profesional. Tujuan besar dari kegiatan PKB 
adalah terwujudnya pembelajaran yang berkualitas untuk meningkatkan kemampuan dalam bidang pengetahuan, keterampilan, dan sikap peserta didik. Ketiga, implementasi manajemen pengembangan keprofesian berkelanjutan mencakup kegiatan perencanaan, pelaksanaan, evaluasi, dan refleksi yang didesain untuk meningkatkan karakteristik, pengetahuan, pemahaman, dan keterampilan. Melalui siklus evaluasi, refleksi pengalaman belajar, perencanaan dan implementasi kegiatan pengembangan keprofesian guru secara berkelanjutan, maka diharapkan guru dan kepala sekolah akan mampu mempercepat pengembangan kompetensi pedagogik, profesional, sosial, dan kepribadian untuk kemajuan karirnya. Keempat, guru dan kepala sekolah dapat mengimplementasikan manajemen pengembangan keprofesian berkelanjutan melalui beberapa program, yaitu: 1) Pengembangan diri, yang meliputi: a) mengikuti diklat fungsional; dan b) melaksanakan kegiatan kolektif guru. 2) Publikasi ilmiah, yang meliputi: a) membuat publikasi ilmiah atas hasil penelitian; dan b) membuat publikasi buku. 3) Karya inovatif, yang meliputi: a) menemukan teknologi tetap guna; b) menemukan/menciptakan karya seni; c) membuat/memodifikasi alat pelajaran; dan d) mengikuti pengembangan penyusunan standar, pedoman, soal dan sejenisnya. Kelima, dengan terwujudnya manajemen pengembangan keprofesian berkelanjutan (PKB) bagi guru dan kepala sekolah yang terprogram secara bertahap dan berjenjang maka diharapkan akan meningkatkan: 1) profesionalisme masingmasing guru dan kepala sekolah; 2) meningkatkan mutu pembelajaran dan kompetensi peserta didik pada penguasaan pengetahuan, ketrampilan, dan sikap; 3) meningkatkan mutu pendidikan secara nasional guna mewujudkan daya saing bangsa Indonesia di era global.

Kata Kunci: Manajemen; Pengembangan; Keprofesiaan; Berkelanjutan; Kepala Sekolah Copyright $\odot$ JMPI: Jurnal Manajemen Pendidikan Islam. All Right Reserved.

This is an open access article under the CC BY-NC-ND license

(http://creativecommons.org/licenses/by-nc-nd/4.0/).

\section{A. PENDAHULUAN}

Kajian ini bertujuan untuk memberikan pemahaman kepada para guru dan kepala sekolah/madrasah serta pihak-pihak yang terkait tentang: 1) kewajiban guru melaksanakan kegiatan pengembangan keprofesian berkelanjutan (PKB) dilaksanakan secara bertahap pada setiap jenjang kepangkatan guru; dan 2) pengembangan keprofesian berkelanjutan dapat meningkatkan profesionalisme guru secara berkelanjutan. Hal ini merujuk pada Peraturan Menteri Negara Pendayagunaan Aparatur Negara dan Reformasi Birokrasi (Permenneg PAN dan RB) Nomor 16 Tahun 2009 (Kemenpan RB, 2013) sebagai penyempurnaan Keputusan Menteri Negara Pendayagunaan Aparatur Negara (Kepmenneg PAN) Nomor 84 Tahun 1993 (Kemenpan RB, 2013) tentang Jabatan Fungsional Guru dan Angka Kreditnya, maka guru mendapatkan peluang semakin luas agar lebih profesional. Tuntutan guru mewujudkannya melalui kegiatan pengembangan profesi yang sekarang disebut dengan Pengembangan Keprofesian Berkelanjutan (PKB).

Pengembangan Keprofesian Berkelanjutan(PKB), yang terdapat dalam buku Pedoman Pengelolaan PKB yang diterbitkan oleh Kementrian Pendidikan Nasional (2011), bahwa PKB adalah bentuk pembelajaran berkelanjutan bagi guru yang merupakan kendaraan utama dalam upaya membawa perubahan yang diinginkan 
berkaitan dengan keberhasilan siswa. Dengan demikian semua siswa diharapkan dapat mempunyai pengetahuan lebih, mempunyai keterampilan lebih baik, dan menunjukkan pemahaman yang mendalam tentang materi ajar serta mampu memperlihatkan apa yang mereka ketahui dan mampu melakukannya. PKB mencakup berbagai cara dan/atau pendekatan dimana guru secara berkesinambungan belajar setelah memperoleh pendidikan dan/atau pelatihan awal sebagai guru. PKB mendorong guru untuk memelihara dan meningkatkan standar mereka secara keseluruhan mencakup bidang-bidang berkaitan dengan pekerjaannya sebagai profesi. Dengan demikian, guru dapat memelihara, meningkatkan dan memperluas pengetahuan dan keterampilannya serta membangun kualitas pribadi yang dibutuhkan di dalam kehidupan profesionalnya.

Dalam buku Pedoman Pelaksanaan Penilaian Kinerja Guru (PK Guru) yang diterbitkan oleh Direktorat Jenderal Peningkatan Mutu Pendidikan dan Tenaga Kependidikan Kementerian Pendiidkan Nasional (2010), diungkapkan bahwa "Guru adalah pendidik profesional yang mempunyai tugas, fungsi, dan peran penting dalam mencerdaskan kehidupan bangsa. Dari ungkapan tersebut maka tidaklah berlebihan kalau dikatakan bahwa masa depan masyarakat, bangsa dan negara, sebagian besar ditentukan oleh guru. Oleh sebab itu, profesi guru perlu dikembangkan secara terus menerus dan proporsional menurut jabatan fungsional guru".

Berangkat dari dasar pemikiran tersebut, berarti guru juga kepala sekolah/madrasah harus mengembangkan profesinya secara terus menerus supaya bisa melaksanakan tugas-tugas, fungsi, dan perannya secara profesional. Strategi dan metode baru yang bisa dikembangkan dalam profesi guru, bisa diperoleh sejalan dengan pengembangan profesi guru secara terus menerus. Pengembangan semacam itu menjadi sangat strategis mengingat tuntutan dalam Peraturan Pemerintah (PP) Nomor 74 Tahun 2008 tentang Guru, yang menjelaskan bahwa "Guru wajib memiliki Kualifikasi Akademik, kompetensi, Sertifikat Pendidik, sehat jasmani dan rohani, serta memiliki kemampuan untuk mewujudkan tujuan pendidikan nasional. Kompetensi Guru meliputi kompetensi pedagogik, kompetensi kepribadian, kompetensi sosial, dan kompetensi profesional yang diperoleh melalui pendidikan profesi". Dalam kompetensi kepribadian, salah satunya menyangkut tentang "mengembangkan diri secara mandiri dan berkelanjutan". Pengembangan profesi guru menjadi sangat penting artinya, sebagai mana tercermin dari apa yang diungkapkan oleh Saud (2009) bahwa untuk meningkatkan mutu pendidikan saat ini, maka profesionalisasi guru (pendidik) merupakan suatu keharusan, terlebih lagi apabila kita melihat kondisi objektif saat ini berkaitan dengan berbagai hal yang ditemui dalam melaksanakan pendidikan, yaitu: (1) perkembangan Iptek, (2) persaingan global bagi lulusan pendidikan, (3) otonomi daerah, dan (4) implementasi kurikulum yang relevan.

Dengan demikian menjadi jelas bahwa pengembangan kemampuan guru dalam melaksanaan tugas, fungsi dan peranannya, merupakan suatu kebutuhan yang harus diterima dan dilaksanakan. Hal ini harus dimaknai sebagai konsekwensi dari profesi yang menuntut harus dilaksanakan secara profesional (Turmuzi, 2015). Berdasarkan dasar pemikiran di atas, maka rumusan masalah yang diajukan dalam penelitian ini adalah:

1. Mengapa guru dan kepala sekolah/madrasah berkewajiban melaksanakan kegiatan PKB secara bertahap pada setiap jenjang kepangkatan mereka? 
2. Bagaimana implementasi pengembangan keprofesian berkelanjutan (PKB) dapat meningktakan profesionalisme guru maupun kepala sekolah/madrasah?

Kajian ini bermanfaat untuk memberikan pemahaman tentang konsep PKB kepada para guru dan kepala sekolah/madrasah serta pihak terkait bahwa PKB dilaksanakan bertahap pada setiap jenjang kepangkatan dan bermanfaat meningkatkan kompetensi menuju guru dan kepala sekolah professional secara berkelanjutan.

\section{B. METODE}

Merujuk pada rumusan masalah dalam penelitian fokus ini, maka jenis penelitian yang dipergunakan adalah penelitian kepustakaan (library research). Dengan library research, maka kajian ini menggunakan metode deskriptif analitik, yaitu data yang diperoleh berupa kata-kata, gambar dan perilaku yang tidak dituangkan dalam bentuk bilangan atau statistik, melainkan tetap dalam bentuk kualitatif dengan memberi pemaparan gambaran mengenai situasi yang diteliti dalam bentuk uraian naratif (Margono, 2000:39). Untuk mempertajam analisis metode deskriptif kualitatif, peneliti menggunakan teknik analisis isi (content analisys), yaitu suatu analisis yang menekankan pada analisis ilmiah tentang isi pesan suatu komunikasi (Moleong, 1990:163-164). Content analisys memanfaatkan prosedur yang dapat menarik kesimpulan shahih dari sebuah buku atau dokumen (Noeng Muhadjir,1992:72). Proses content analisys adalah dimulai dari isi pesan komunikasi tersebut, dipilah-pilah (disortir), kemudian dilakukan kategorisasi (pengelompokan) antara data yang sejenis, dan selanjutnya dianalisis secara kritis dan obyektif (Josep Bleicher, 1980:28).

Jenis data yang diperlukan dalam penelitian ini adalah data kualitatif yang sifatnya tekstual. Sumber data dipilah menjadi tiga, yaitu: sumber data primer, sekunder dan penunjang. Adapun data primer penelitian ini adalah data kepustakaan yang menjadi sumber utama dalam kajian ini, yaitu: 1) Kemenpan RB (2013) tentang Peraturan Menteri Negara Pendayagunaan Aparatur Negara dan Reformasi Birokrasi Nomor 16 Tahun 2009 tentang Jabatan Fungsional Guru dan Angka Kreditnya; 2) Kementrian Pendidikan dan Kebudayaan (2012) tentang Buku 1 Pedoman Pengelolaan Pengembangan Keprofesian Berkelanjutan; 3) Peraturan Menteri Pendidikan Nasional Nomor 35 Tahun 2010 Tentang Petunjuk Teknis Jabatan Fungsional Guru dan Angka Kreditnya, Kemendiknas, Jakarta 2010; dan 4) Peraturan Pemerintah RI Nomor 74 Tahun 2008 tentang Guru (Lembaran Negera RI Tahun 2008 Nomor 194).

Sedang data sekunder dan data penunjang yaitu sejumlah dokumen kepustakaan lainnya maupun hasil download di internet yang mendukung terhadap kajian manajemen pengembangan keprofesian berkelanjutan bagi guru dan kepala sekolah/madrasah.

\section{HASIL DAN PEMBAHASAN}

Berdasarkan rumusan masalah yang diajukan dan metode penelitian yang digunakan maka hasil penelitian dan pembahasan kajian ini dapat diuraikan sebagai berikut:

\section{Pengertian PKB}

Pengembangan Keprofesian Berkelanjutan (PKB) adalah pengembangan kompetensi guru yang dilaksanakan sesuai dengan kebutuhan, bertahap, berkelanjutan 
untuk meningkatkan profesionalitasnya (berdasarkan Permenneg PAN dan Reformasi Birokrasi Nomor 16 Tahun 2009).

Pengertian utuh dari Pengembangan Keprofesian Berkelanjutan (PKB), yang terdapat dalam buku Pedoman Pengelolaan PKB yang diterbitkan oleh Kementrian Pendidikan Nasional (2011), bahwa: PKB adalah bentuk pembelajaran berkelanjutan bagi guru yang merupakan kendaraan utama dalam upaya membawa perubahan yang diinginkan berkaitan dengan keberhasilan siswa. Dengan demikian semua siswa diharapkan dapat mempunyai pengetahuan lebih, mempunyai keterampilan lebih baik, dan menunjukkan pemahaman yang mendalam tentang materi ajar serta mampu memperlihatkan apa yang mereka ketahui dan mampu melakukannya. PKB mencakup berbagai cara dan/atau pendekatan dimana guru secara berkesinambungan belajar setelah memperoleh pendidikan dan/atau pelatihan awal sebagai guru. PKB mendorong guru untuk memelihara dan meningkatkan standar mereka secara keseluruhan mencakup bidang-bidang berkaitan dengan pekerjaannya sebagai profesi. Dengan demikian, guru dapat memelihara, meningkatkan dan memperluas pengetahuan dan keterampilannya serta membangun kualitas pribadi yang dibutuhkan di dalam kehidupan profesionalnya.

Profesi sebagai guru maupun tugas tambahan sebagai kepala sekolah/madrasah mengemban amanah yang berat. Amanah itu antara lain adalah mencerdaskan peserta didik sehingga mereka kelak di kemudian hari mampu menjalani kehidupannya dengan bekal pendidikan yang diberikan gurunya. Sejalan dengan hal itu, Trimo (2008) mengemukakan bahwa pekerjaan sebagai guru menjadi lebih berat tatkala menyangkut peningkatan kemampuan peserta didiknya sedangkan kemampuan dirinya mengalami stagnasi. Oleh karena itu, guru perlu bahkan harus terus mengembangkan dirinya. Unsur kegiatan PKB terdiri dari tiga macam kegiatan yaitu: pengembangan diri, publikasi ilmiah dan karya inovatif.

\section{Tujuan, Manfaat dan Sasaran PKB}

Berdasarkan Buku 1 Pedoman Pengelolaan Pengembangan Keprofesian Berkelanjutan: Pembinaan Pengembangan Profesi Guru yang diterbitkan oleh Pusat Pengembangan Profesi Pendidik, Badan pengembangan Sumber Daya Manusia Pendidikan dan Kebudayaan dan Penjaminan Mutu Pendidian Kementerian Pendidikan dan Kebudayaan tahun 2012 dijelaskan tentang Tujuan, Manfaat, dan Sasaran Pengembangan Keprofesian Berkelanjutan (PKB).

a. Tujuan Pengembangan Keprofesian Berkelanjutan (PKB)

Tujuan umum pengembangan keprofesian berkelanjutan (PKB) adalah untuk meningkatkan kualitas layanan pendidikan di sekolah/madrasah dalam rangka meningkatkan mutu pendidikan. Sedangkan secara khusus tujuan pengembangan keprofesian berkelanjutan adalah sebagai berikut:

1) Meningkatkan kompetensi guru untuk mencapai standar kompetensi yang ditetapkan dalam peraturan perundangan yang berlaku.

2) Memutakhirkan kompetensi guru untuk memenuhi kebutuhan guru dalam perkembangan ilmu pengetahuan, teknologi dan seni untuk memfasilitasi proses pembelajaran peserta didik.

3) Meningkatkan komitmen guru dalam melaksanakan tugas pokok dan fungsinya sebagai tenaga profesional.

4) Menumbuhkan rasa cinta dan bangga sebagai penyandang profesi guru. 
5) Meningkatkan citra, harkat, dan martabat profesi guru di masyarakat.

6) Menunjang pengembangan karir guru.

b. Manfaat Pengembangan Keprofesian Berkelanjutan (PKB)

Manfaat pengembangan keprofesian berkelanjutan yang terstruktur, sistematik dan memenuhi kebutuhan peningkatan keprofesian guru adalah sebagai berikut:

1) Bagi Peserta Didik. Dengan adanya pelaksanaan PKB, maka peserta didik memperoleh jaminan pelayanan dan pengalaman belajar yang efektif.

2) Bagi Guru. Kepada guru dengan melaksanakan PKB (pengembangan keprofesian berkelanjutan) akan dapat memenuhi standar dan mengembangkan kompetensinya sehingga mampu melaksanakan tugas-tugas utamanya secara efektif sesuai dengan kebutuhan belajar peserta didik untuk menghadapi kehidupan di masa datang.

3) Bagi Sekolah/Madrasah. Sekolah/Madrasah akan mampu memberikan pelayanan pendidikan yang lebih baik dan berkualitas bagi peserta didik.

4) Orang tua/masyarakat memperoleh jaminan bahwa anak mereka mendapatkan layanan pendidikan yang berkualitas dan pengalaman belajar yang efektif.

5) Bagi Pemerinta, dengan adanya PKB akan memberikan jaminan kepada masyarakat tentang layanan pendidikan yang berkualitas dan profesional.

c. Sasaran Pengembangan Keprofesian Berkelanjutan (PKB)

Sasaran kegiatan pengembangan keprofesian berkelanjutan adalah semua guru pada satuan pendidikan yang berada di lingkungan Kementerian Pendidikan dan Kebudayaan, Kementerian Agama, dan/atau Kementerian lain, serta satuan pendidikan yang diselenggarakan oleh masyarakat.

(http:/ / penelitiantindakankelas.blogspot.com/, 2013b).

\section{Prinsip-prinsip Dasar Pelaksanaan PKB}

Paling tidak ada 9 prinsip dasar yang harus dipenuhi dalam pelaksanaan

Pengembangan Keprofesian Berkelanjutan (PKB) untuk guru (http://penelitiantindakankelas.blogspot.com/2014) yang sekaligus menjadi tugas dan kebijakan kepala sekolah / madrasah, yaitu:

a. PKB harus fokus kepada keberhasilan peserta didik atau berbasis hasil belajar peserta didik. Oleh karena itu, PKB harus menjadi bagian integral dari tugas guru dan kepala sekolah sehari-hari. Hal ini tentu saja wajar karena tujuan dari pengembangan keprofesian berkelanjutan pada muaranya adalah hasil belajar siswa yang meningkat. Sebagai output dari proses pembelajaran, kualitas siswa merupakan bukti bahwa telah terjadi peningkatan profesionalisme oleh guru dan kepala sekolah yang bersangkutan.

b. Setiap guru berhak mendapat kesempatan untuk mengembangkan diri yang perlu diimplementasikan secara teratur, sistematis, dan berkelanjutan. Untuk menghindari kemungkinan pengalokasian kesempatan pengembangan yang tidak merata, proses penyusunan program PKB harus dimulai dari sekolah. Begitu besarnya jumlah guru di Indonesia tentu saja membuat pelaksanaan program pengembangan keprofesian berkelanjutan harus direncanakan dengan baik. Pelaksanaan program ini harus diatur sedemikian rupa, sistematis, dan bersifat terus-menerus, agar terjadi peningkatan kualitas guru di negeri ini.

c. Sekolah/madrasah wajib menyediakan kesempatan kepada setiap guru untuk mengikuti program PKB dengan minimal jumlah jam per tahun sesuai dengan yang 
ditetapkan dalam Peraturan Menteri Negara Pemberdayaan Aparatur Negara dan Reformasi Birokrasi Nomor 16 Tahun 2009. Dinas Pendidikan dan Kementerian Agama di tingkat Kabupaten/Kota maupun pada satuan pendidikan di setiap sekolah/madrasah berhak menambah alokasi waktu jika dirasakan perlu. Program pengembangan keprofesian berkelanjutan bukan saja kewajiban bagi guru, akan tetapi itu sudah merupakan haknya. Profesi guru menuntut perkembangan yang terus-menerus dari guru. Guru tidak dapat diam di tempat. Ia harus terus belajar dan mengembangkan diri untuk menjadi sosok yang profesional dan bermartabat.

d. Bagi guru yang tidak memperlihatkan peningkatan setelah diberi kesempatan untuk mengikuti program PKB sesuai dengan kebutuhannya, maka dimungkinkan diberikan sanksi sesuai dengan ketentuan perundang-undangan. Sanksi tersebut tidak berlaku bagi guru, jika sekolah/madrasah tidak dapat memenuhi kebutuhan guru untuk melaksanakan program PKB. Hal ini mungkin pernyataan yang sedikit mendorong guru-guru kita untuk bersikap serius untuk melakukan kegiatan pengembangan keprofesian berkelanjutan. Hal ini wajar dilakukan pemerintah karena bagaimanapun juga guru adalah ujung tombak peningkatan kualitas pendidikan di negeri ini.

e. Cakupan materi untuk kegiatan PKB harus terfokus pada pembelajaran peserta didik, kaya dengan materi akademik, proses pembelajaran, penelitian pendidikan terkini, dan teknologi dan/atau seni, serta menggunakan pekerjaan dan data peserta didik untuk meningkatkan kualitas pembelajaran. Hal ini antara lain dimaksudkan agar kegiatan pengembangan keprofesian berkelanjutan yang dilakukan oleh seorang guru benar-benar membawa manfaat, dan berdampak besar bagi peningkatan kualitas kompetensinya sebagai guru yang profesional.

f. Proses PKB bagi guru harus dimulai dari guru sendiri. Oleh karena itu, untuk mencapai tujuan PKB, kegiatan pengembangan harus melibatkan guru secara aktif sehingga betul-betul terjadi perubahan pada dirinya, baik dalam penguasaan materi, pemahaman konteks, keterampilan, dan lain-lain sesuai dengan tujuan peningkatan kualitas layanan pendidikan di sekolah/madrasah termasuk di lingkungan pendidikan PAUD dan TK.

g. PKB yang baik harus berkontribusi untuk mewujudkan visi, misi, dan nilai-nilai yang berlaku di sekolah/madrasah dan/atau kabupaten/kota. Oleh karena itu, kegiatan PKB harus menjadi bagian terintegrasi dari rencana pengembangan sekolah/madrasah dan/atau kabupaten/kota dalam melaksanakan peningkatan mutu pendidikan yang disetujui bersama antara sekolah/madrasah, orangtua peserta didik, dan masyarakat.

h. Sedapat mungkin kegiatan PKB dilaksanakan di sekolah/madrasah atau dengan sekolah/madrasah di sekitarnya (misalnya di gugus KKG atau MGMP) untuk menjaga relevansi kegiatannya dan juga untuk mengurangi dampak negatif pada lingkungan yang disebabkan jika guru dalam jumlah besar bepergian ke tempat lain.

i. $\quad$ PKB harus mendorong pengakuan profesi guru menjadi lapangan pekerjaan yang bermartabat dan memiliki makna bagi masyarakat dalam pencerdasan bangsa, dan sekaligus mendukung perubahan khusus di dalam praktik-praktik dan pengembangan karir guru yang lebih obyektif, transparan dan akuntabel. 
Adapun uraian tentang prinsip-prinsip dasar pelaksanaan Pengembangan Keprofesian Berkenajutan bagi guru dan kepala sekolah/madrasah sebagaimana uraian di atas dapat dibagankan sebagai berikut:

Gambar 1. Prinsip-prinsip Dasar Pelaksanaan PKB bagi Guru

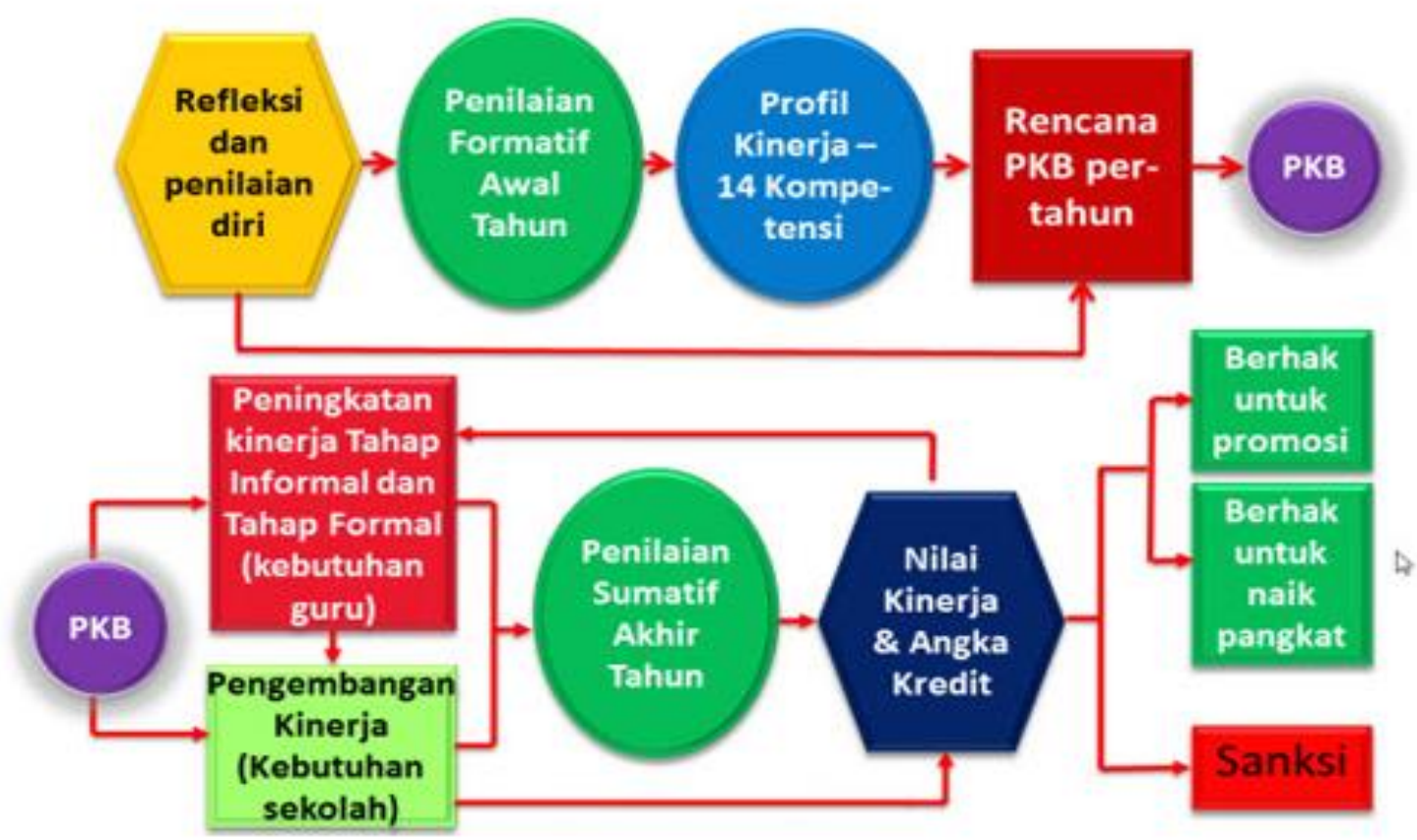

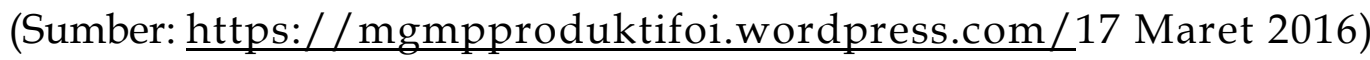

\section{Komponen PKB}

Adapun komponen PKB yang bisa diikuti oleh guru, yang mana tertuang dalam buku Pedoman Pengelolaan PKB (2011) sebagaimana pada Gambar 1, secara singkat mencakup:

a. Pengembangan diri, yang meliputi: 1) mengikuti diklat fungsional; dan 2) melaksanakan kegiatan kolektif guru.

b. Publikasi ilmiah, yang meliputi: 1) membuat publikasi ilmiah atas hasil penelitian; dan 2) membuat publikasi buku.

c. Karya inovatif, yang meliputi: 1) menemukan teknologi tetap guna; 2) menemukan/menciptakan karya seni; 3) membuat/memodifikasi alat pelajaran; dan 4) mengikuti pengembangan penyusunan standar, pedoman, soal dan sejenisnya.

Gambar 2. Komponen PKB bagi Guru dan Kepala Sekolah 


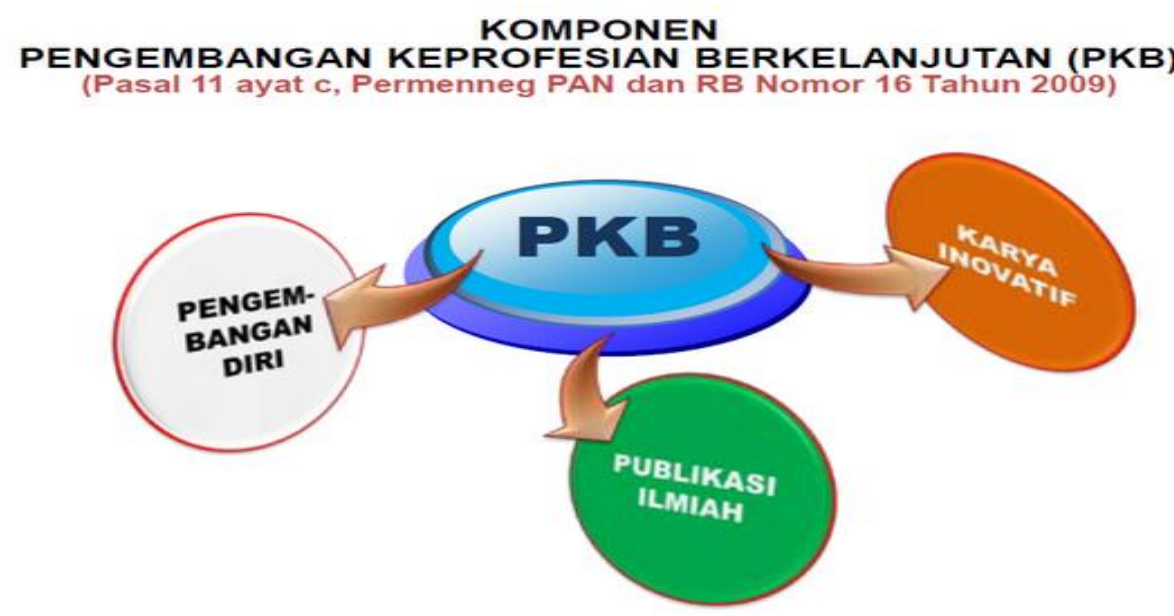

(Sumber: https://mgmpproduktifoi.wordpress.com/17 Maret 2016)

\section{Implementasi Manajamen Pengembangan Keprofesian Berkelanjutan}

Berdasarkan laporan hasil praktek di lapangan, MGMP-Produktif SMK Kabupaten Ogan Ilir Provinsi Sumatera Selatan (2016), implementasi manajemen pengembangan keprofesian berkelanjutan bagi guru dan kepala sekolah/madrasah maka dapat dilakukan melalui tahapan sebagi berikut:

a. Setiap awal tahun semua guru berkoordinasi dengan kepala sekolah wajib melakukan evaluasi diri untuk merefleksikan kegiatan yang telah dilakukan pada tahun ajaran sebelumnya. Evaluasi diri dan refleksi merupakan dasar bagi seorang guru dan kepala sekolah untuk menyusun rencana kegiatan pengembangan kprofesian yang akan dilakukan pada tahun tersebut. Bagi guru yang mengajar pada lebih dari satu sekolah, maka kegiatan evaluasi diri dilakukan di sekolah induknya. Evaluasi diri dilakukan dengan mengisi Format -1 (satu) yang memuat antara lain:

1) Deskripsi evaluasi diri terhadap butir-butir dimensi tugas utama/indikator kinerja guru, kompetensi untuk menghasilkan publikasi ilmiah dan karya inovatif, kompetensi lain yang dimiliki untuk menunjang pelaksanaan pembelajaran yang berkualitas (misalnya TIK, Matematika, bahasa Asing, dsb), dan kompetensi lain yang dimiliki untuk melaksanakan tugas tambahan (misalnya Kepala Sekolah, Kepala Perpustakaan, Kepala Bengkel, Kepala Laboratorium, dsb).

2) Deskripsi usaha-usaha yang telah guru lakukan untuk memenuhi dan mengembangkan berbagai kompetensi tersebut.

3) Deskripsi kendala yang guru hadapi dalam memenuhi dan mengembangkan berbagai kompetensi yang terkait dengan pelaksanaan tugas utama/indikator kinerja guru dan/atau kinerja guru dengan tugas tambahan.

4) Deskripsi pengembangan keprofesian berkelanjutan yang masih guru butuhkan dalam memenuhi dan mengembangkan berbagai kompetensi dan dimensi tugas utama/indikator kinerja guru.

b. Hasil evaluasi diri guru yang dilengkapi dengan dokumen pendukung antara lain perangkat pembelajaran yang telah disiapkan oleh guru yang bersangkutan selanjutnya akan digunakan untuk menentukan profil kinerja guru dalam menetapkan apakah guru akan mengikuti program peningkatan kinerja untuk 
mencapai standar kompetensi profesi atau kegiatan pengembangan kompetensi lebih lanjut.

c. Melalui konsultasi dengan Kepala Sekolah, Guru dan Koordinator Pengembangan Keprofesian Berkelanjutan membuat perencanaan kegiatan pengembangan keprofesian berkelanjutan (menggunakan Format-2). Konsultasi ini diperlukan untuk menentukan apakah kegiatan Pengembangan Keprofesian Berkelanjutan dilaksanakan di sekolah, di KKG/MGMP/MGBK, dan/atau di LPMP/PPPPTK. Apabila kegiatan Pengembangan Keprofesian Berkelanjutan dilaksanakan di luar sekolah, perlu dikoordinasikan dengan KKG/MGMP/MGBK dan koordinator pengembangan keprofesian berkelanjutan di tingkat kabupaten/kota.

d. Koordinator pengembangan keprofesian berkelanjutan tingkat sekolah bersama dengan Kepala Sekolah, menetapkan dan menyetujui rencana final kegiatan pengembangan keprofesian berkelanjutan bagi guru (Format 2-3). Perencanaan tersebut memuat kegiatan pengembangan keprofesian berkelanjutan yang akan dilakukan oleh guru baik secara mandiri dan/atau bersama-sama dengan guru lain di dalam sekolah, di KKG/MGMP/MGBK maupun kegiatan yang akan dilaksanakan oleh Dinas Pendidikan. Dinas Pendidikan diharapkan dapat memfasilitasi kegiatan pengembangan keprofesian berkelanjutan yang akan dilaksanakan di kabupaten/kota dan memberikan anggaran atau subsidi kepada sekolah maupun KKG/MGMP/MGBK.

e. Guru menerima rencana program pengembangan keprofesian berkelanjutan yang mencakup kegiatan yang akan dilakukan di dalam dan/atau luar sekolah. Rencana kegiatan pengembangan keprofesian berkelanjutan juga mencakup sasaran yang akan dicapai dalam kurun waktu tertentu setelah guru mengikuti program pengembangan keprofesian berkelanjutan. Jika diperlukan, dalam melaksanakan kegiatan pengembangan keprofesian berkelanjutan, seorang guru dapat menerima pembinaan berkelanjutan dari seorang guru pendamping. Guru pendamping tersebut ditetapkan oleh kepala sekolah dengan syarat telah berpengalaman dalam melaksanakan proses pembelajaran dan telah mencapai standar kompetensi yang telah ditetapkan serta memiliki kinerja minimal baik berdasarkan hasil penilaian kinerja guru.

f. Guru selanjutnya melaksanakan kegiatan pengembangan keprofesian berkelanjutan yang telah direncanakan baik di dalam dan/atau di luar sekolah. sekolah berkewajiban menjamin bahwa kesibukan guru melaksanakan kegiatan pengembangan keprofesian berkelanjutan tidak mengurangi kualitas pembelajaran peserta didik.

Bagi guru yang telah memiliki kompetensi sesuai standar atau di atas standar:

1) Program pengembangan keprofesian berkelanjutan (Diklat Pengembangan) diarahkan kepada peningkatan dan pengembangan kompetensi terkait dengan pelaksanaan tugas utama/kinerja guru, pengembangan model pembelajaran aktif dan materi-materi ajar berbasiskan IT/ICT, serta pengembangan kompetensi untuk menghasilkan publikasi ilmiah/karya inovatif.

2) Dengan demikian guru akan memiliki ilmu pengetahuan yang kuat, tuntas dan tidak setengah-tengah serta memiliki kepribadian yang matang dan seimbang agar mampu memberikan layanan pendidikan sesuai dengan perkembangan masa kini. 
Bagi guru yang belum mencapai standar kompetensi yang dipersyaratkan, maka program pengembangan keprofesian berkelanjutannya diarahkan kepada pencapaian standar kompetensi melalui diklat lanjutan dengan mempertimbangkan beberapa hal berikut:

1) jenis kompetensi yang perlu ditingkatkan

2) daya dukung yang tersedia di sekolah

3) catatan hasil evaluasi diri dan hasil penilaian kinerja guru

4) target dan jadwal perubahan/peningkatan yang diharapkan akan terjadi setelah guru mengikuti kegiatan pengembangan keprofesian berkelanjutan untuk mencapai standar kompetensi yang dipersyaratkan.

5) Dalam pelaksanaan pengembangan keprofesian berkelanjutan bagi guru yang belum mencapai kompetensi standar dapat didampingi oleh Guru pendamping.

6) Mekanisme pelaksanaan penanganan guru yang belum memenuhi standar yang ditetapkan adalah sebagai berikut:

Informal; Pada tahap ini guru yang bersangkutan (didampingi kepala sekolah, koordinator Pengembangan Keprofesian Berkelanjutan, dan Guru Pendamping) menganalisis hasil penilaian kinerja guru dan kemungkinan solusinya untuk pengembangan lebih lanjut kompetensi yang nilainya masih di bawah standar. Apakah nilai yang belum memenuhi standar dimaksud berasal dari isu terkait dengan ilmu pengetahuan (yang tidak cukup atau yang keliru)? Ataukah masalah ini merupakan refleksi dari masalah pedagogik? Ataukah masaIah kepribadian?

Pada tahap ini guru diberi waktu antara 6-8 minggu untuk melaksanakan pengembangan keprofesian berkelanjutan secara mandiri. Di akhir pelaksanaan pengembangan keprofesian berkelanjutan secara mandiri akan dilakukan observasi ulang oleh penilai. Semua kegiatan guru selama tahap ini termasuk hasil diskusi pada pelaksanaan observasi ulang dicatat secara tertulis dalam buku/folder khusus. Buku/folder khusus ini digunakan sebagai sumber penyusunan laporan pelaksanaan pengembangan keprofesian secara mandiri yang disyahkan oleh kepala sekolah. Laporan ini selanjutnya dapat digunakan sebagai bukti pelaksanaan pengembangan diri yang dimungkinkan dapat diberikan angka kredit. Apabila hasil observasi ulang belum menunjukan peningkatan maka guru masuk dalam tahap semi formal. Akan tetapi apabila dalam tahap ini sudah menunjukkan hasil observasi ulang yang signifikan maka guru langsung mengikuti kegiatan pengembangan keprofesian berkelanjutan untuk pengembangan selanjutnya.

Semi-formal; Jika hasil observasi pada tahap informal menunjukkan belum ada peningkatan kompetensi yang ingin dicapai, maka penilai dapat mengusulkan kepada koordinator pengembangan keprofesian berkelanjutan agar guru diberikan kesempatan untuk mengikuti tahap semi formal. Pada tahap ini, program pembinaan lebih terstruktur dan guru harus bekerja sama dengan seorang guru pendamping. Dengan dukungan guru pendamping, guru melakukan kegiatan peningkatan kompetensi yang diperlukan selama 6-8 minggu melalui kegiatan kolektif guru di KKG/MGMP. Di akhir pelaksanaan pengembangan keprofesian berkelanjutan tahap semi-formal akan dilakukan 
observasi ulang oleh penilai. Semua kegiatan guru selama tahap ini termasuk hasil diskusi pada pelaksanaan observasi ulang dicatat secara tertulis dalam buku/folder khusus. Buku/folder khusus ini digunakan sebagai sumber penyusunan laporan pelaksanaan pengembangan keprofesian tahap semiformal yang disyahkan oleh kepala sekolah. Laporan tersebut selanjutnya dapat digunakan sebagai bukti pelaksanaan pengembangan diri yang dimungkinkan dapat diberikan angka kredit.

Apabila hasil observasi ulang belum menunjukan peningkatan, maka guru harus mengikuti tahap formal. Akan tetapi apabila dalam observasi ulang tahap semi-formal guru telah menunjukkan peningkatan kompetensi secara signifikan maka guru langsung mengikuti kegiatan pengembangan lebih lanjut.

Formal; Jika hasil observasi ulang pada tahap informal dan semi-formal belum menunjukkan peningkatan kompetensi standar, maka pembinaan guru dilakukan melalui tahapan formal. Pada tahap formal ini, guru dikirimkan oleh sekolah untuk mengikuti pengembangan keprofesian berkelanjutan di lembaga pelatihan (misalnya P4TK, PT/LPTK, dan service provider lainnya) melalui proses pengawasan oleh kepala sekolah. Kegaitan observasi ulang akan dilakukan setelah pelaksanaan pengembangan keprofesian berkelanjutan tahap formal selama 6-8 minggu sesuai kesepakatan bersama. Semua kegiatan guru selama tahap ini termasuk hasil diskusi pada pelaksanaan observasi ulang dicatat secara tertulis dalam buku/folder khusus. Buku/folder khusus ini digunakan sebagai sumber penyusunan laporan pelaksanaan pengembangan keprofesian tahap formal yang disyahkan oleh kepala sekolah. Laporan tersebut selanjutnya dapat digunakan sebagai bukti pelaksanaan pengembangan diri yang dimungkinkan dapat diberikan angka kredit.

Apabila hasil observasi ulang belum menunjukan peningkatan, maka guru yang bersangkutan ikut kembali dalam siklus penanganan kinerja guru yang belum memenuhi standar sebagai mana diuraikan dalam mekanisme di atas. Akan tetapi apabila dalam tahap ini sudah menunjukkan tahap yang signifikan terkait dengan peningkatan kompetensinya maka guru dapat langsung mengikuti kegiatan pengembangan lebih lanjut.

Jika pengulangan dua siklus di atas sudah dilaksanakan akan tetapi belum memenuhi kompetensi standar yang ditetapkan, maka kepada guru dimaksud akan diberikan sanksi sesuai dengan ketentuan yang berlaku.

g. Setelah mengikuti program pengembangan keprofesian berkelanjutan, guru wajib mengikuti penilaian kinerja guru di akhir semester. Penilaian kinerja guru di akhir semester tersebut dimaksudkan untuk melihat peningkatan kompetensi yang telah dicapai oleh guru setelah melaksanakan pengembangan keprofesian berkelanjutan. Selain itu, hasil penilaian kinerja yang diperoleh akan dikonversi ke perolehan angka kredit. Gabungan angka kredit perolehan dari penilaian kinerja guru dan pengembangan keprofesian berkelanjutan yang telah diikuti guru akan diperhitungkan untuk kenaikan pangkat dan jabatan fungsional guru serta merupakan bahan pertimbangan untuk pemberian tugas tambahan atau pemberian sanksi bagi guru. Sebagai bukti bahwa guru telah melaksanakan kegiatan pengembangan keprofesian berkelanjutan guru diwajibkan membuat deskripsi diri 
terkait dengan kegiatan pegembangan keprofesianberkelanjutan yang dilaksanakan dan dilampirkan dalam usulan angka kreditnya.

h. Di akhir semester, semua guru dan koordinator pengembangan keprofesian berkelanjutan tingkat sekolah melakukan refleksi apakah kegiatan pengembangan keprofesian berkelanjutan yang telah diikutinya benar-benar bermanfaat dalam meningkatkan kompetensi guru dalam melaksanakan pembelajaran. (Format-4).

Dalam pelaksanaan manajemen pengembangan keprofesian berkelanjutan sebagaimana dijelaskan pada tahapan tersebut perlu dilakukan kegiatan monitoring dan evaluasi. Kegiatan monitoring dan evaluasi tersebut dilakukan oleh Koordinator pengembangan keprofesian berkelanjutan kabupaten/kota bekerjasama dengan Koordinator pengembangan keprofesian berkelanjutan tingkat sekolah. Kegiatan monitoring dan evaluasi ini dimaksudkan untuk mengetahui apakah kegiatan pengembangan keprofesian berkelanjutan yang dilaksanakan dapat mencapai tujuan yang telah ditetapkan. Kegiatan monitoring dan evaluasi direncanakan dan dilaksanakan dengan aktivitas mengkaji kekuatan, permasalahan dan hambatan serta pemecahannya untuk perbaikan kegiatan pengembangan keprofesian berkelanjutan di masa mendatang. Kegiatan monitoring dan evaluasi yang dilakukan oleh koordinator dilaksankaan pada pertengahan pelaksanaan kegiatan Pengembangan Keprofesian Berkelanjutan (https://mgmpproduktifoi.wordpress.com/, 2016).

Menurut Jafar Sarifudin (2019) dari SMPN 1 Gandrungmangu Cilacap menjelaskan bahwa dalam rangka mengimplementasikan Pengembangan Keprofesian Berkelanjutan (PKB) guna mewujudkan Best Practice (pengalaman terbaik) kinerja guru dan kepala sekolah, maka penting daya dukung dari Peningkatan Kompetensi Berkelanjutan (PKP). Tahapan ini dapat diwujudkan sebagaimana gambar berikut:

Gambar 3. Tahapan Implementasi Manajemen PKB bagi Guru dan Kepala Sekolah

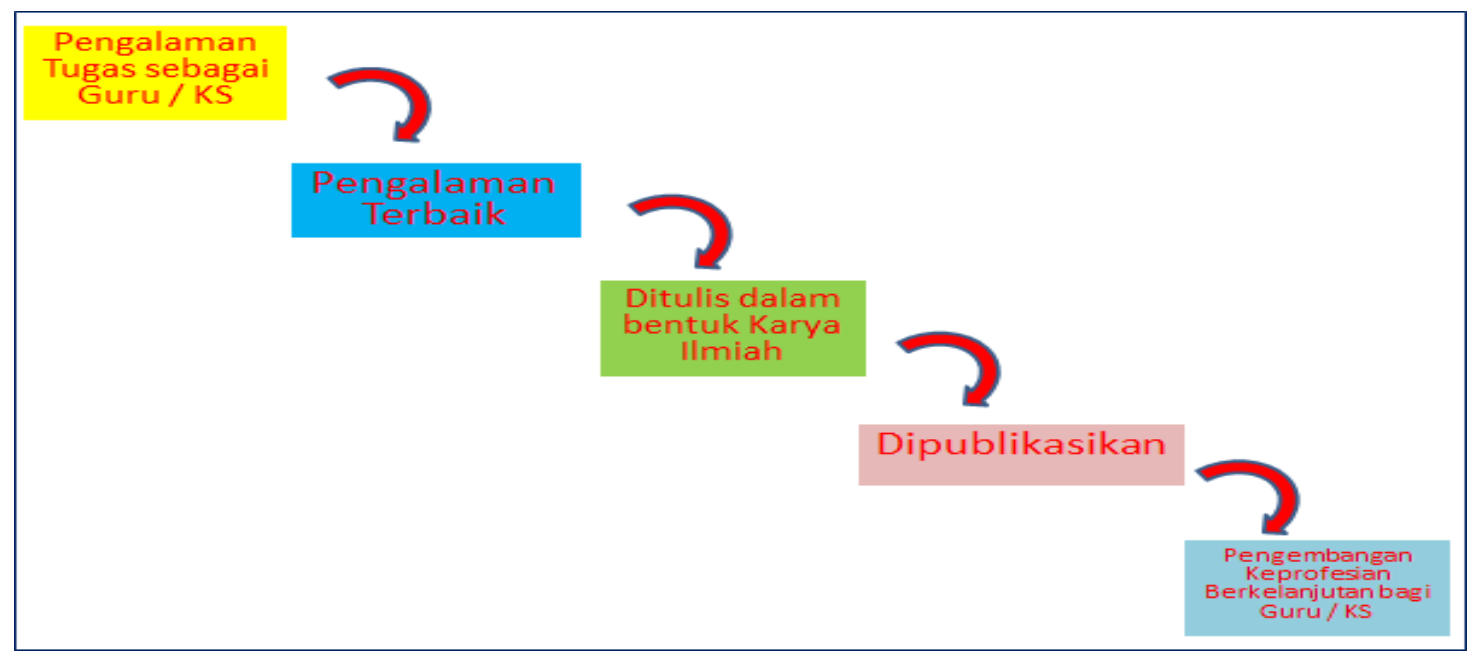

(Sumber: http://traheni.blogspot.com/, 24 Oktober 2019)

\section{PKB dan Kenaikan Pangkat Guru}

Kegiatan PKB yang disesuaikan dengan jenjang kepangkatan guru menunjukkan bahwa PKB dilaksanakan secara bertahap dan berkesinambungan. Guru tidak mungkin secara tiba-tiba dipaksa untuk melaporkan hasil penelitian yang telah dilakukannya 
dalam bentuk buku, jurnal, dan seterusnya. Di awal karier guru, guru melakukan kegiatan pengembangan diri, setelahnya publikasi ilmiah dan atau karya inovatif yang bertahap sesuai dengan jenjang. Dengan demikian guru profesional terbentuk dengan pola belajar seumur hidup yang mengedepankan semangat hari esok harus lebih baik daripada hari ini.

Gambar 3. Hubungan PKB dan Kenaikan Pangkat Guru

\begin{tabular}{|c|c|c|c|c|c|}
\hline \multirow{3}{*}{$\begin{array}{l}\text { Guru } \\
\text { Pertama }\end{array}$} & Donara Muids Itha & $10+3$ & AKK & АКРКB & AKP \\
\hline & 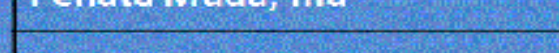 & & 50 & $3 \mathrm{pd}, 0 \mathrm{pi} / \mathrm{ki}$ & 5 \\
\hline & Penata Muda Tingkat I, IIIb & 150 & 50 & 3 pd, 4 pi $/ \mathrm{ki}$ & 5 \\
\hline \multirow{2}{*}{$\begin{array}{l}\text { Guru } \\
\text { Muda }\end{array}$} & Penata, IIIc & 200 & 100 & 3 pd, 6 pi/ki & 10 \\
\hline & Penata Tingkat I, IIId & 300 & 100 & $4 \mathrm{pd}, 8 \mathrm{pi} / \mathrm{ki}$ & 10 \\
\hline \multirow{3}{*}{$\begin{array}{l}\text { Guru } \\
\text { Madya }\end{array}$} & Pembina, IVa & 400 & 150 & 4 pd, 12 pi/ki & 15 \\
\hline & Pembina Tingkat I, IVb & 550 & 150 & 4 pd,12pi/ki & 15 \\
\hline & Pembina Utama Muda, IVc & 700 & 150 & $5 \mathrm{pd}, 14 \mathrm{pi} / \mathrm{ki}$ & 15 \\
\hline \multirow{2}{*}{$\begin{array}{l}\text { Guru } \\
\text { Utama }\end{array}$} & Pembina Utama Madya, IVd & 850 & 200 & 5 pd,20 pi/ki & 20 \\
\hline & Pembina Utama, IVe & 1050 & & & \\
\hline $\begin{array}{l}\text { AKK : } \\
\text { AKPKB : } \\
\text { AKP : }\end{array}$ & $\begin{array}{l}\text { Angka Kredit Komulatif } \\
\text { Angka Kredit PKB } \\
\text { Angka Kredit unsur Penunjang }\end{array}$ & & & & \\
\hline
\end{tabular}

(Sumber: https://mgmpproduktifoi.wordpress.com/,17 Maret 2016)

PKB dilaksanakan sesuai dengan kebutuhan, secara bertahap, berkelanjutan untuk meningkatkan profesionalitas guru. Bagi seorang guru pemula yang berada di jenjang III/a tentu yang diperlukan adalah kompetensi guru sesuai jenjangnya (dalam diklat fungsional) dan menambah pengetahuan-pengalaman sebanyak-banyaknya dari rekan guru termasuk yang senior dalam melakukan tugas (kegiatan kolektif guru). Namun, setelah guru berada pada jenjang III/b sampai dengan III/d, kegiatan PKB guru hendaknya meliputi publikasi ilmiah dan atau karya inovatif. Mulai III/d ke atas guru wajib menyusun laporan penelitian dan variasi dari jenis kegiatan publikasi ilmiah lainnya sesuai dengan jenjangnya.

\section{KESIMPULAN}

Berdasarkan hasil penelitian dan pembahasannya di atas maka penelitian ini dapat disimpulkan sebagai berikut: Dari uraian materi ini dapat dirangkum sebagai berikut: Pertama, pemberlakukan Peraturan Menteri Negara Pendayagunaan Aparatur Negara dan Reformasi Birokrasi (Permenneg PAN dan RB) Nomor 16 Tahun 2009 sebagai penyempurnaan Keputusan Menteri Negara Pendayagunaan Aparatur Negara (Kepmenneg PAN) Nomor 84 Tahun 1993 tentang Jabatan Fungsional Guru dan Angka Kreditnya, maka guru dan kepala sekolah/madrasah mendapatkan semakin luas agar 
lebih profesional. Tuntutan guru dan kepala sekolah/madrasah mewujudkannya melalui kegiatan pengembangan profesi yang sekarang disebut sebagai pengembangan keprofesian berkelanjutan (PKB). Pengembangan keprofesian berkenajutan (PKB) adalah pengembangan kompetensi guru secara pribadi maupun dengan tugas tambahan sebagai kepala sekolah/madrasah dengan yang dilaksanakan sesuai dengan kebutuhan, bertahap, berkelanjutan untuk meningkatkan profesionalitasnya.

Kedua, PKB adalah sebuah bentuk pembelajaran berkelanjutan bagi guru yang merupakan suatu jalan utama dalam upaya membawa perubahan-perubahan yang berkaitan dengan keberhasilan peserta didik, sehingga siswa diharapkan mempunyai pengetahuan, keterampilan/skill yang lebih, dan mampu memahami materi secara mendalam. Dengan adanya PKB, guru dan kepala sekolah mampu membangkitkan minat peserta didik khususnya dalam ilmu pengetahuan dan teknologi. Guru-guru yang profesional sangat diperlukan sebagai penunjang pembangunan negara secara menyeluruh, karena guru-guru yang profesional mampu melahirkan golongan cendekiawan yang nantinya akan meneruskan generasi bangsa Indonesia

Ketiga, menjadi seorang guru apalagi sebagai kepala sekolah / madrasah sangat membutuhkan skill/kemampuan dalam proses peningkatan pendidikan. Bukan hanya itu, guru juga harus memiliki karakter khusus dalam mengajar. PKB merupakan wadah suatu pencerahan dan penawaran bermakna bagi seorang guru. Karena PKB memberikan suatu pembelajaran berkelanjutan bagi guru maupun kepala sekolah /madrasah yang merupakan kendaraan utama dalam upaya membawa perubahan yang diinginkan berkaitan dengan peserta didik. Menjadi seorang guru bukan berarti berhenti belajar karena guru-pun harus berguru. Maka dari itu mengikuti pelatihan yang membantu meningkatkan kualitas guru maupun keberhasilan peserta didik sangatlah perlu diikuti oleh seorang guru demi terwujudnya pendidikan yang berkarakter dan menghasilkan tenaga profesional serta peserta didik yang memiliki kualitas tinggi. Tujuan besar atas keberhasilan implementasi manajemen pengembangan keprofesian berkelanjutan (PKB) bagi guru maupun kepala sekolah/madrasah menjadi soko guru utama untuk membangun mutu pendidikan nasional guna mewujudkan daya saing bangsa Indonesia di era global.

\section{REFERENSI}

Blog Penelitian Tindakan Kelas (PTK). (2013), Dasar Hukum Pelaksanaan Pengembangan Keprofesian Berkelanjutan (PKB), Tuesday, November 12, 2013, [Tersedia] http://penelitiantindakankelas.blogspot.com/, [Online] Sabtu, 21 Desember 2019:10.07.

Blog Penelitian Tindakan Kelas (PTK). (2014). Prinsip-prinsip Dasar Pelaksanaan Pengembangan Keprofesian Berkelanjutan (PKB), Friday, October 24, 2014, [Tersedia] http://penelitiantindakankelas.blogspot.com/, [Online] Sabtu, 21 Desember 2019:10.04.

Kamilati, Nurul. (2016). Pengembangan Keprofesian Berkelanjutan Mewujudkan Guru yang Profesional. Makalah, (Semarang: Balai Diklat Keagamaan Semarang, 2016). [Tersedia] https://bdksemarang.kemenag.go.id/, [Online] Sabtu, 21 Desember 2019:08.34. 
Kamilus, Moh., Zaman. (2017). Pengembangan Keprofesian Berkelanjutan (PKB) Guru PAI [Tersedia] http://kamiluszaman.blogspot.com/, Sunday, July 9, 2017 at 01:31 AM [Online] Sabtu, 21 Desember 2019:09.01.

Kementerian Negara Pendayagunaan Aparatur Negara dan Reformasi Birokrasi. (2013). Peraturan Menteri Negara Pendayagunaan Aparatur Negara dan Reformasi Birokrasi Nomor 16 Tahun 2009 tentang Jabatan Fungsional Guru dan Angka Kreditnya, Jakarta.

Kementerian Pendidikan dan Kebudayaan. (2012). Buku 1 Pedoman Pengelolaan Pengembangan Keprofesian Berkelanjutan, Jakarta.

Kementrian Pendidikan Nasional, Derektorat Jenderal Peningkatan Mutu Pendidikan dan Tenaga Kependidikan, (2010). Pedoman Pelaksanaan Penilaian Kinerja Guru (PK Guru), Jakarta.

Kementrian Pendidikan Nasional, Pusat Pengembangan Profesi Pendidik Badan Pengembangan Sumber Daya Manusia Pendidikan dan Penjaminan Mutu Pendidikan. (2011). Pedoman Pengelolaan Pengembangan Keprofesian Berkelanjutan (PKB) (Buku 1), Jakarta.

Kementrian Pendidikan Nasional, Pusat Pengembangan Profesi Pendidik Badan Pengembangan Sumber Daya Manusia Pendidikan dan Penjaminan Mutu Pendidikan. (2011). Pedoman Pengelolaan Pengembangan Keprofesian Berkelanjutan (PKB) (Buku 4), Jakarta.

Kementrian Pendidikan Nasional, Pusat Pengembangan Profesi Pendidik Badan Pengembangan Sumber Daya Manusia Pendidikan dan Penjaminan Mutu Pendidikan. (2011). Pedoman Pengelolaan Pengembangan Keprofesian Berkelanjutan (PKB) (Buku 5), Jakarta.

MGMP-Produktif SMK Kabupaten Ogan Ilir Provinsi Sumatera Selatan. (2016). Unsur, Mekanisme Da Bukti Fisik Pengembangan Keprofesian Berkelanjutan, 17 Maret 2016, [Tersedia] https://mgmpproduktifoi.wordpress.com/, [Online] Selasa, 16 Juni 2020:18.13.

Pemerintah Republik Indonesia, Undang-undang Nomor 14 Tahun 2005 tentang Guru dan Dosen, Jakarta, 2005.

Peraturan Menteri Pendidikan Nasional Nomor 35 Tahun 2010 Tentang Petunjuk Teknis Jabatan Fungsional Guru dan Angka Kreditnya, Kemendiknas, Jakarta 2010.

Peraturan Pemerintah RI Nomor 74 Tahun 2008 tentang Guru (Lembaran Negera RI Tahun 2008 Nomor 194).

Saefudin, Udin, Saud. (2009). Pengembangan Profesi Guru, Bandung: CV. Alfabeta.

Sarifudin, Jafar. (2019). Best Practice sebagai Pengembangan Keprofesian Berkelanjutan (PKB) melalui Peningkatan Kompetensi Berkelanjutan (PKP), SMPN 1 Gandrungmangu Cilacap, 24 Oktober 2019, [Tersedia] http://traheni.blogspot.com/, [Online] Selasa, 16 Juni 2020:18.22.

Turmuzi, Ahmad. (2015). Pengembangan Keprofesian Berkelanjutan (PKB): Peluang Peningkatan Karir Guru, 24 Oktober 2011:00:59 diperbarui: 26 Juni 2015:00:35, [Tersedia] https://www.kompasiana.com/, [Online] Sabtu, 21 Desember 2019:10.09. 